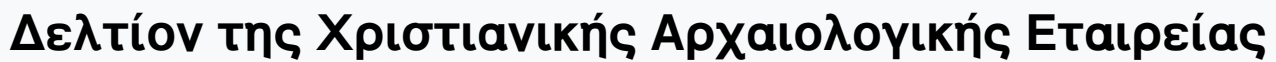

Tó 24 (2003)

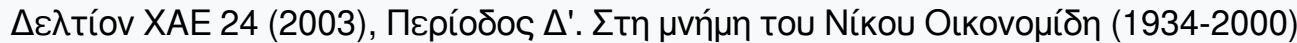

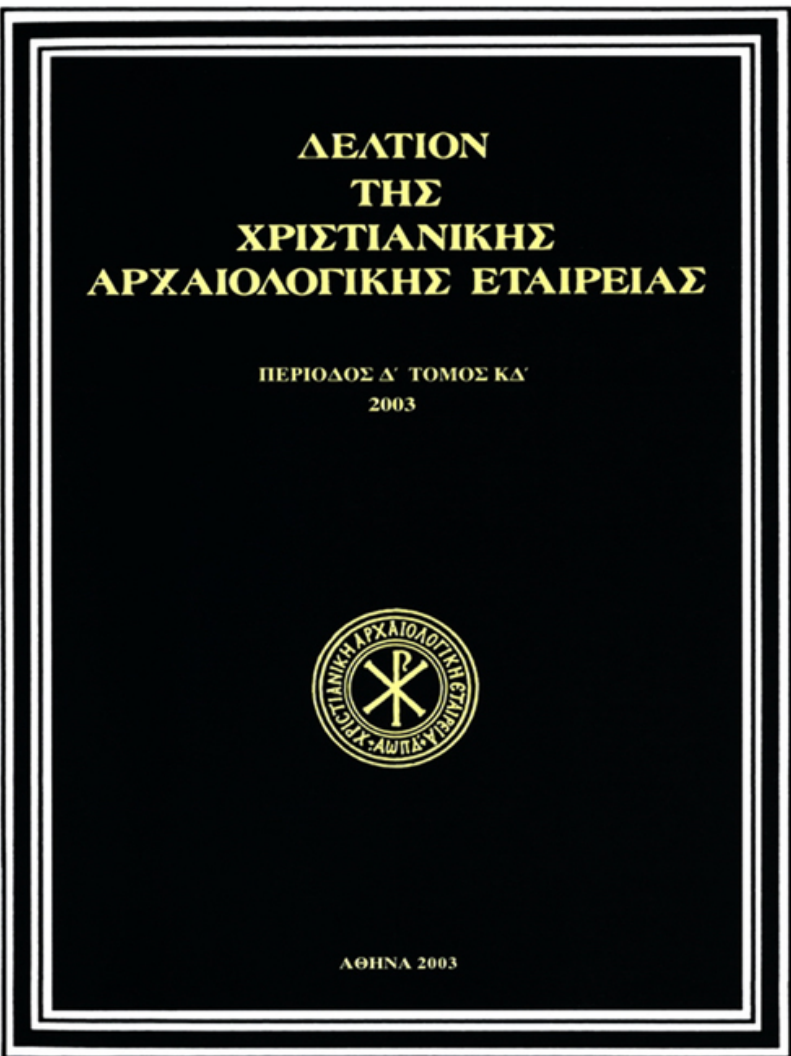

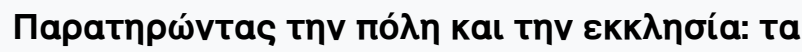

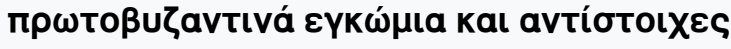

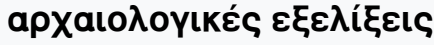

Helen SARANTI

doi: $10.12681 /$ dchae.364

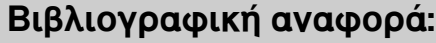

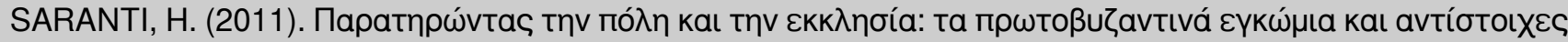

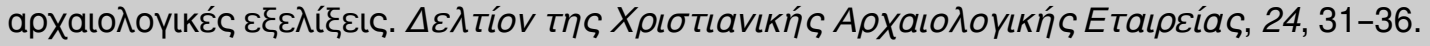

https://doi.org/10.12681/dchae.364 


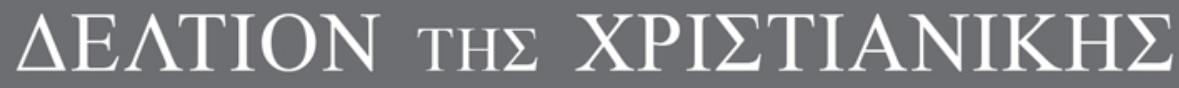 APXAIO $\Lambda$ ОГКН $\Sigma$ ETAIPEIA $\Sigma$}

Beholding the City and the Church: The Early Byzantine Ekphraseis and Correspoding Archaeological Evidence

Helen SARANTI

Tómos KA' (2003) • $\Sigma \varepsilon \lambda .31-36$

A@HNA 2003 


\section{BEHOLDING THE CITY AND THE CHURCH: THE EARLY BYZANTINE EKPHRASEIS AND CORRESPONDING ARCHAEOLOGICAL EVIDENCE}

$\mathrm{D}$ escriptions and praises of cities (ekphraseis and enkomiastikai ekphraseis) were an attractive theme of early Byzantine rhetoric. They appear also as a component of various literary genres including historiography ${ }^{1}$. While such descriptions followed rhetorical rules established earlier by orators of the Roman empire, especially Menander, the originality of each ekphrasis consists in the ways the theme of the praised city was used, the creative adaptation of the topoi in each literary work and the translation of rhetorical clichés to a new context. One of the themes developed in some early Byzantine texts is that of the praised city as seen by the orator who describes it. The visual comprehension and the visual or eye contact is known from earlier Greek literature, especially the epic and erotic poetry ${ }^{2}$. It was rather typical in descriptions of art objects of the Roman period, when the narrator described the object as he saw it with a formulaic language with the verb óga $\omega$ or its synonyms ${ }^{3}$. In ekphraseis of cities of the Roman period, the description was usually done without the involvement of the author as a viewer ${ }^{4}$. In contrast, in the early Byzantine literature we observe a

1. C.J. Classen, Die Stadt im Spiegel der Descriptiones und Laudes urbium in der antiken und mittelalterlichen Literatur bis zum Ende des zwölften Jahrhunderts, Zürich, New York 1986. H. Saradi, The Kallos of the Byzantine City: The Development of a Rhetorical Topos and Historical Reality, Gesta 34/1 (1995), p. 37-56.

2. Cf., for example, G. Nagy, Irreversible Mistakes and Homeric Poetry, in Euphrosyne. Studies in Ancient Epic and its Legacy in Honor of Dimitris N. Maronitis (eds J.N. Kazazis and A. Rengakos), Stuttgart 1999, p. 261. 3. Cf. Philostratus the Elder, Imagines, I.1.1, 2; 4.3; 6.3, 7 etc; Philostratus the Younger, Imagines, 2.2, 4; 3.1, 4, 5; 5.2, etc; Callistratus, Descriptions, $1.3,5 ; 2.3 ; 3.2,4,5$, etc. This had roots in earlier literature. Cf., for example, J.B. Burton, Theocritus's Urban Mimes. Mobility, Gender, and Patronage, Berkeley, Los Angeles, London 1995, p. 97 and n. 24.

4. Cf., for example, Aelius Aristides' Panathenaikos (ed. F. W. Lenz and C.A. Behr), P. Aelii Aristidis Opera, Lugduni Batavorum 1976, c. $351 \mathrm{ff}$. with the city's description. There is only a reference to the theme of be-

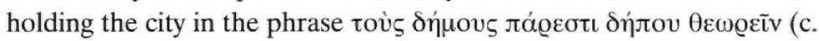

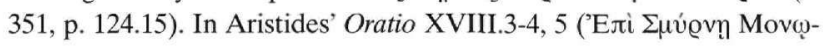

change in the treatment of the subject: the author states clearly that he observes the described city. Drawing on rhetorical conventions, this involves an emphasis on the visual aspects of the description, which produces vividness ${ }^{5}$. At the same time the process of viewing the city creates a sense of emotional involvement of the viewer. The distance between the author and the described city of the earlier style of description is eliminated. The narrator who is the eyewitness of his object of praise now produces a sense of closeness.

Libanius in his Antiochikos (Oration XI) in praise of the city of Antioch repeats the theme of beholding the city in a variety of images. The imperial palace on the island of Orontes offered a splendid view of the city: "It reaches to the middle of the island, which we have called an omphalos, and extends to the outer branch of the river, so that where the wall has columns instead of battlements, there is a view worthy of the emperor, with the river flowing below and the suburbs

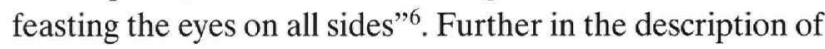
the suburb of Daphne the orator describes vividly the superlative beauty of the site and the spectator's emotional re-

$\delta i \alpha)$ the act of viewing the city is formulated in a comparison with that

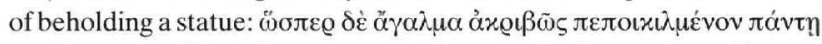

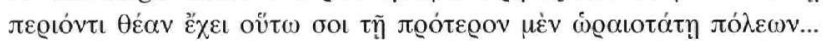

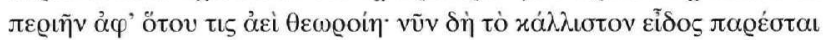

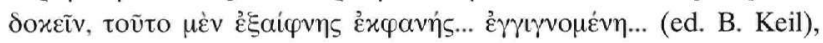

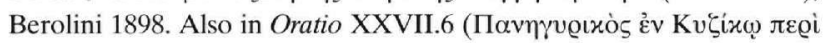

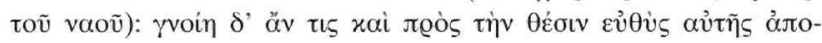
$\beta \lambda \dot{\psi} \psi \alpha \varsigma$...

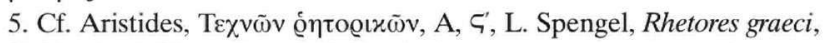

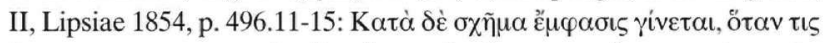

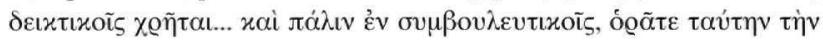

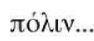

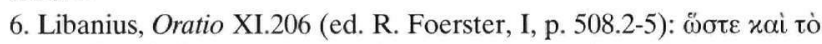

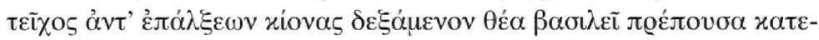

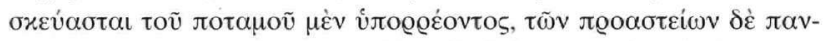

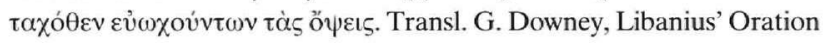
in Praise of Antioch (Oration XI). Translated with Introduction and Commentary, PAPS 103 (1959), p. 675. 
action to the display of physical and architectural beauty: "When a man sees this he cannot but cry out and leap for joy and skip and clap his hands and bless himself for seeing the sight, and, so to speak, soar on wings from pleasure. One thing from one side and one thing from another enchants and astonishes; one thing holds one, and another tears one away, and there pours upon the spectator's eyes an arresting brightness, the temple of Apollo, the temple of Zeus, the Olympic stadium, the theatre which furnishes every pleasure, the number and thickness and height of the cypresses, the shady paths, the choruses of singing birds, the even breeze, the odors sweeter than spices, the stately aqueducts, the vines trained to form banqueting halls..."

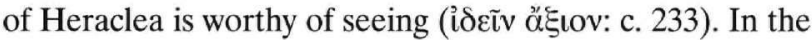
Monody for Nicomedia, the orator laments the city's destruction by an earthquake with emotional tones. He is pre-

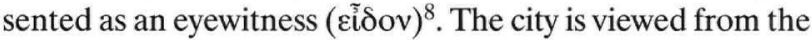
sea up to the hill, while to those coming from the mountain it appears below splendid ${ }^{9}$. In Oration XIII.19 referring to the studies of the emperor Julian in Athens, the visual contact with the city is emphatically repeated: Julian looked at the

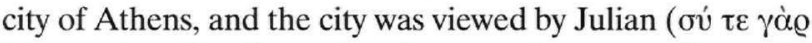

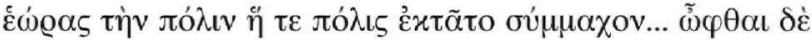

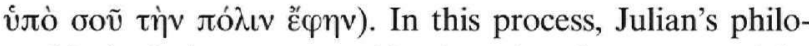
sophical mind was captured by the cultural greatness of the eternal city. It was a way of experiencing the city. The theme of beholding the described object reappears in Libanius' Ekphraseis of works of art ${ }^{10}$.

In the Dionysiaka of Nonnus of Panopolis, references to the visual comprehension are abundant in a variety of contexts ${ }^{11}$.
The city of Tyre is described with lyric tones, baroque taste of Asianic rhetoric, and Dionysian passion. The god Dionysus is presented approaching Tyre, looking at its location from a distance, praising the beauties of its idyllic surroundings, and being captured by a love for the city. City and surrounding countryside are described with vivid words as if the reader were a spectator ${ }^{12}$. Tyre is presented through the eyes of the god who is shown wandering "through the city casting his eyes about"13. The god admires the city's architectural features: the streets, the fountains and the splendid glorious monuments ${ }^{14}$. Aphrodite modelled the city of Beirut after renowned ancient cities which she saw through her mind: "she sent her imagination wandering swiftly round, and driving her mind to wander about the whole earth surveyed the foundations of the brilliant cities of ancient days"15. She looked at Athens, saw there the column of Solon's Laws, "and turned aside her eye to the broad streets of Athens"16. Envying Athena, she made Beirut a major centre of legal studies.

In Nonnus' epic, we detect two models of seeing the city. The one is panoramic, when the god approaches from a distance and sees the city as a broad transversal picture. This model of seeing recalls the Hellenistic planning of cities built on hills and offering a splendid view to the approaching visitor. Similar was the description of Nicomedia by Libanius. At the same time, however, the gods of the Dionysiaka experienced the city-space directly with a visual comprehension of the city's interior, by physically moving through the streets and the buildings or by focussing the eyes on specific urban features, or through a mental observation. The reader through the eyes and the mind of the gods and in direct con-

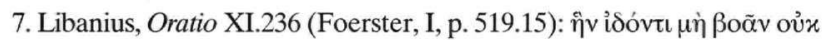

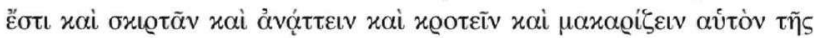

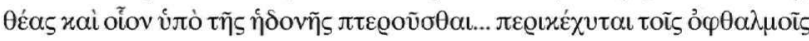

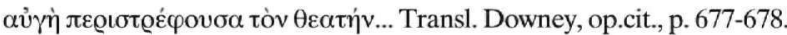
8. Oratio LXI.8 (Foerster, IV, p. 333.13).

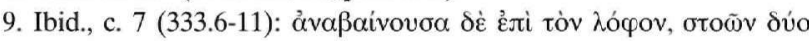

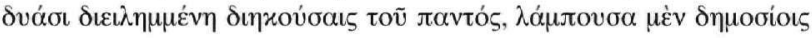

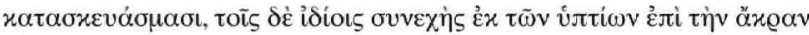

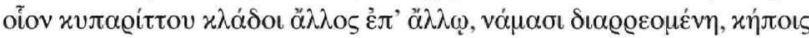

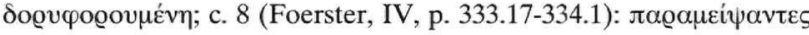

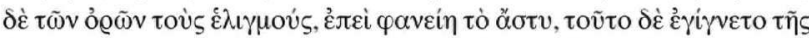

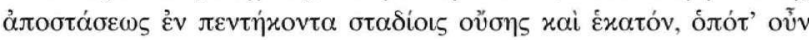

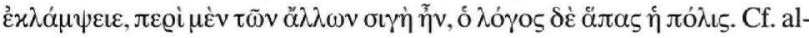

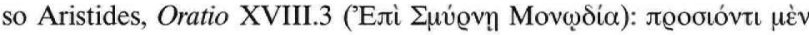

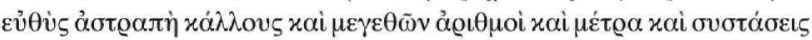

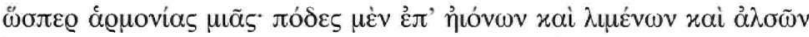

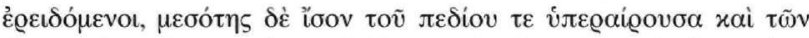

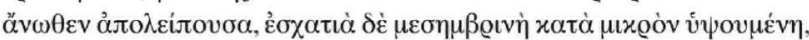

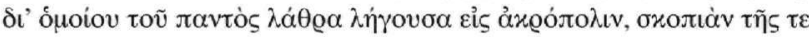

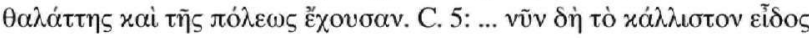

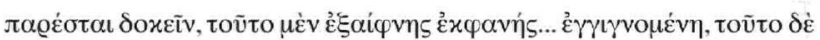

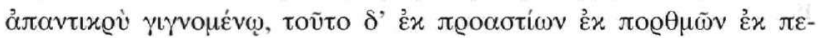

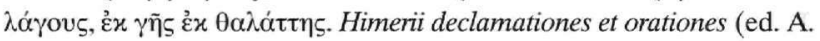
Colonna), Romae 1951, Or. XXXIX.7 (p. 162, 11. 53-57).

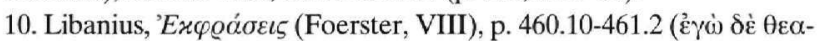

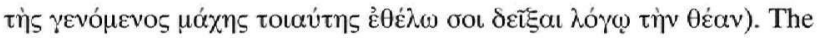

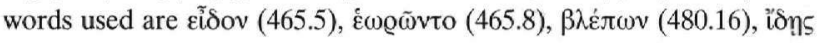

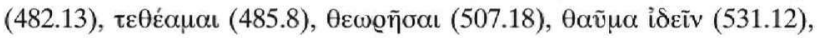
etc. In the description of a beautiful girl the erotic theme imposes a greater development of the topos: $\tau$ น (544.9), i $\delta \omega v$ (545.15), and the reaction of the viewer and the response of the person viewed through the eye-contact (545.15-24).

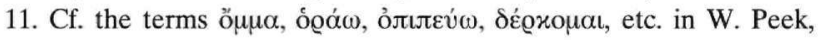
Lexikon zu den Dionysiaka des Nonnos, Berlin 1968.

12. Nonnus, Dionysiaka, XL.304-336 (ed. B. Simon), Paris 1999.

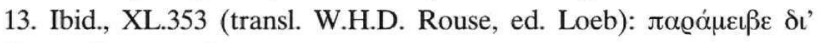

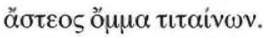

14. Ibid., XL.353-365.

15. Ibid., XLI.264-266 (transl. Rouse, op.cit.).

16. Ibid., XLI. 274. 
tact with the city pervades the urban space. This focus on parts of the city recalls depictions of urban segments in Roman paintings ${ }^{17}$.

The theme of beholding the city, implying an immediate contact with the urban space, is not found in the literature of the sixth century. Instead, in church descriptions the theme of beholding the church is developed in a variety of rhetorical compositions. In addition, such descriptions do not isolate the church from the city but they emphatically refer to the urban context of the churches. In the first enkomion of bishop Marcian of Gaza by the orator Choricius, we find a strategy of parallels between church and city, a play between connection and dominance. Choricius praises bishop Marcian by including in his oration an enkomiastike ekphrasis, a praise of the church of St Sergius constructed by him. The orator begins the description of the church by explaining to those who were viewing it what was the purpose of his oration. He stresses repeatedly the act of beholding the church, and that his description aimed at offering an imitation of the viewed monument: "To those of you, who are viewing it [the church] I may perhaps appear to be doing something superfluous. For if the purpose of an oration is to imitate that

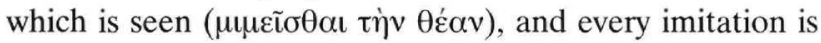
somehow inferior to the real thing, it is evident that I entertain you less than a pleasure that appears through the eyes ( written account will, I think, instruct more vividly than an imprecise verbal report - those who have not experienced

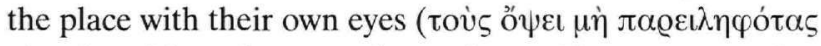

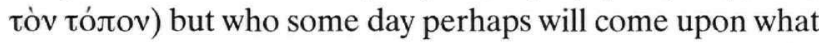
is being said [in this oration]; and even more to the point, the oration offers a certain pleasure to those who are seeing it

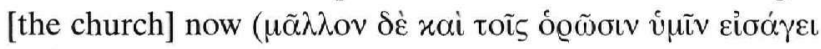

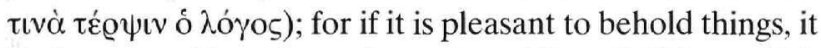

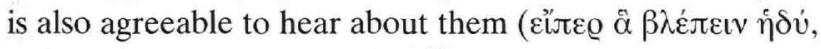

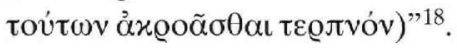

17. Lise Bek, 'Venusta Species'. A Hellenistic Rhetorical Concept as the Aesthetic Principle in Roman Townscape, Analecta Romana Instituti Danici 14 (1985), p. 139-148.

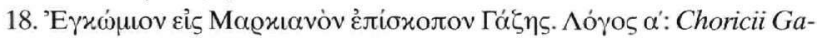
zaei opera (eds R. Foerster, E. Richtsteig), Leipzig 1929, c. 16 (p. 7), transl. F. K. Litsas, Choricius of Gaza: An Approach to his Work (Introduction, Translation, Commentary), PhD, Univ. of Chicago, p. 115. On the construction of the early Byzantine ekphrasis of the Christian church cf. R. Macrides and P. Magdalino, The Architecture of Ekphrasis: Construction and Context of Paul the Silentiary's Poem on Hagia Sophia, BMGS 12 (1988), p. 47-82. Cf. also R. Webb, The Aesthetics of Sacred Space: Narrative, Metaphor, and Motion in Ekphraseis of Church Buildings, DOP 53 (1999), p. 59-74.
The visitor walking to the north approaches the church from the agora, turning to the left. There the propylon of the church makes a strong impression on him and he is puzzled as to whether to stay longer and enjoy its architectural beauty or enter the church and the internal beauty of the building $^{19}$. In the first and in the second enkomion for bishop Marcian, Choricius stresses the aesthetic importance of the propylon and the colonnaded forecourt in various literary modes: their ornamental role and their practical function as shelters from the rain ${ }^{20}$. The theme has been celebrated in Libanius' Antiochikos ${ }^{21}$. Choricius applies it to the church's exterior colonnades. The strategy of parallels between traditional urban features and Christian churches is found also in another passage in the first oration: the four columns from Carystos inside the church of St Sergius were superior to those in the portico of the agora both "in size and in the beauty of their placement" 22 . In another section, the orator pushes the theme of the city's connection with the church even further. He creates a unique parallel of the praised church of St Sergius with the cities of the empire in a twofold composition. First, cities famous for the production of marble supplied the material for the construction of the church, and they take pride in it. Second, the church is found to have received all of the fame, which some cities enjoyed for construction of palaces, their beautiful location, the quality of their materials, their size and the brightness of their paintings ${ }^{23}$. In this comparison, the church and the cities share equal fame. The elaborate rhetorical composition elevating the excellence of the church to that of the cities is novel, having only a thin precedent in the Oration XXVII of Aelius Aristides $^{24}$.

Choricius repeats the topos of beholding the church in his description of the interior. The visitor upon entering the church would observe everything, turning his eyes to each one of the interior elements of the church: "Thus, entering the church, you will be astounded by the diverse beauty of

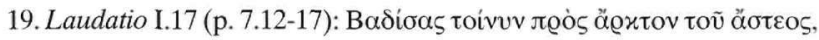

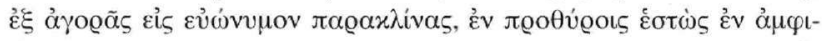

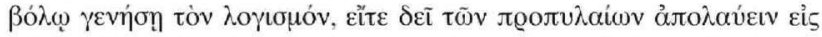

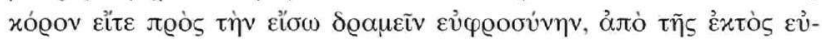

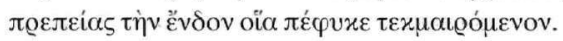

20. Laudatio I.17 and 18 (p. 7); II.30-34 (p. 35-37).

21. Libanius, Oratio XI.196-202, 213-218.

22. Choricius, Laudatio I.18 (p. 7), transl. Litsas, op.cit., p. 115.

23. Ibid., I.41-43 (p. 13).

24. The theme may derive from a passage of Aelius Aristides in the Oratio XXVII.19 where the size of the sanctuary of Kyzikos is compared to

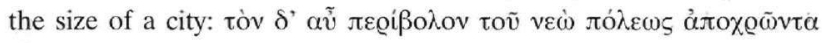

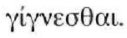




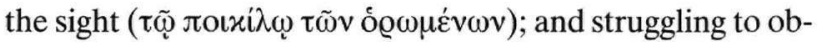
serve everything at once, while your eyes glance here and there, and trying not to pass over anything without seeing,

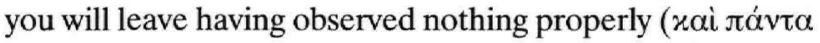

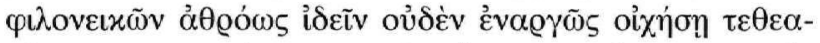

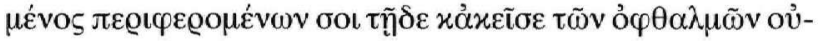

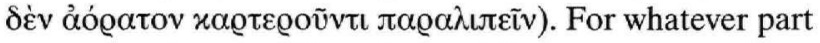
you may omit, you will lose the best"25.

In the second praise of Marcian, Choricius returns to the theme of beholding the church and its architectural features in the description of the churches of St Sergius and St Stephanus ${ }^{26}$. The church of St Stephanus was notably visible from afar and guided the visitor to it after he had descended

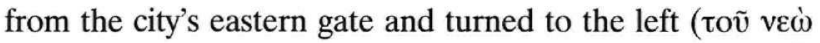

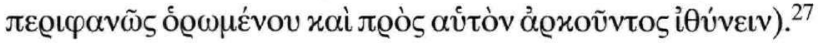
The theme of urban landmarks making the city visible is known from rhetorical treatises ${ }^{28}$. The church was built on a high ground and it was approached through a great number of steps $^{29}$. In the oration in praise of dux Aratius and archon Stephanus, Choricius returns to the theme of the interplay of the city and the church. Archon Stephanus contributed with

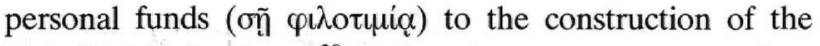
church of St Stephanus ${ }^{30}$. Its location was most appropriate for pointing to the city from afar while guiding spiritually

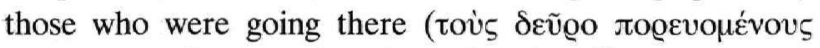

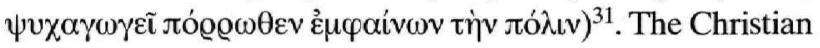
message, implied by the verb $\psi v \chi \alpha \gamma \omega \gamma \tilde{\omega}$, is artfully intertwined with the image of the city, which emerges still powerful next to that of the church. Now the view of the city from afar is dominated by the Christian church.

Procopius, in his Buildings, describes the church of Saint Sophia rebuilt by Justinian after its destruction during the Nika revolt. He praises the superlative excellence of the church, its grandiose architectural plan, the variety of materials and colours. The building, as described by Procopius, is transformed by religion into the place where mystical experiences and contacts with the divine are achieved. Procopius begins his praise with the word $\theta \dot{\varepsilon} \alpha \mu \alpha$, spectacle, an emphat-

25. Choricius, Laudatio I.23 (transl. Litsas, op.cit., p. 117). Cf. also c. 24 :

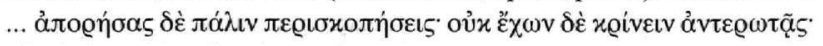

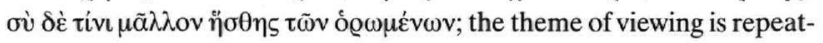
ed in c. 36,39 (p. 12), 45 (p. 14), 54 (p. 16).

26. Ibid., II.21 (p. 33), 26 (p. 35), 34 (p. 36-37), 36 (p. 37), 49 (p. 40 ), 57 (p. 42).

27. Ibid., II.28 (p. 35).

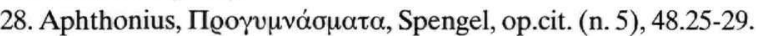

29. Choricius, Laudatio II.29 (p. 35.22).

30. Ibid., III.60 (p. 64.10-11).

31. Ibid., III.61 (p. 64.14-15). ic rhetorical device ${ }^{32}$, calling for a visual comprehension of the building: "So the church has become a spectacle of marvellous beauty, overwhelming to those who see it, but to those who know it by hearsay altogether incredible" ${ }^{\prime 3}$. He returns to the theme of beholding in the description of the architectural parts of the interior (arches, the dome, etc.): “... and yet do not permit the spectator to linger much over the study of any one of them, but each detail attracts the eye

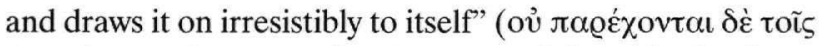

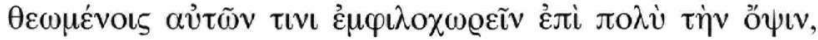

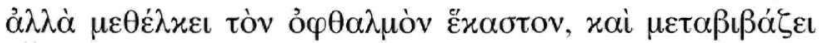

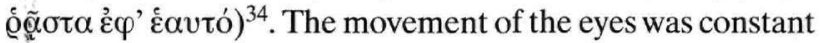

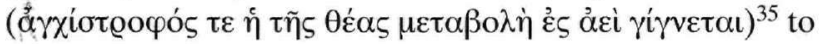
observe the multitude of architectural forms and their harmonious combination in a broad synthesis. The beholder

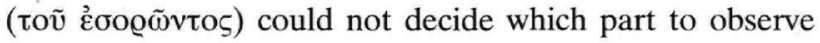
and admire more than the others. Viewing is further emphasized with a reference to the beholders' "contracted brows"

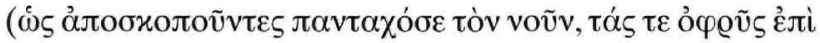

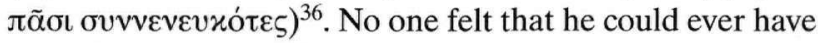
enough of the magnificence and the beauty of the spectacle

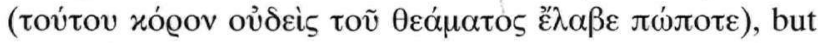
people inside the church enjoyed what they saw ( $\mu \varepsilon \dot{v} 0 ı$ ) and made it subject of their conversation ${ }^{37}$.

In the first section of his description, Procopius connects the church with the city by placing it into the urban setting in a composition of balance and contrast. We may easily discern a similarity in language and in thematic motif with the descriptions of Choricius mentioned above. Using opposition in the ideas and the forms of the composition ${ }^{38}$, the images of the church and of the city are intermingling, the one complementing the other: "For it (the church) soars to a height to match the sky, and as if surging up from amongst the other buildings it stands on high and looks down upon the remainder of the city, adorning it, because it is a part of it, but glorying in its own beauty, because, though a part of the city and dominating it, it at the same time towers above it to such a height that the whole city is viewed from there as from a

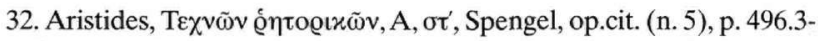

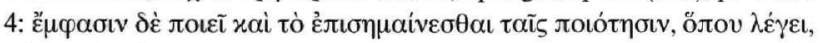

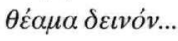

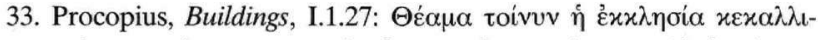

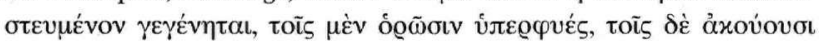

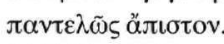

34. Ibid., I.1.47.

35. Ibid., I.1.48.

36. Ibid., I.1.49.

37. Ibid., I.1.63.

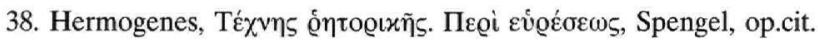


watch-tower" 39 . It would appear that this way of viewing the city and the church from a distance continues the Hellenistic description of a townscape ${ }^{40}$, as we have identified it in Libanius' Monody of Nicomedia, and in the Dionysiaka of Nonnus. Procopius describes the church of Saint Sophia as rising high up to the sky above the other buildings of the city. Below, the church beautifies the city. The church is intimately connected with the city: it belongs to it by being part of it. Yet, the church dominates the city with its mass and majesty of construction. From its height, the spectator could enjoy a panoramic view of the entire city. Next to the Hellenistic and the Roman ways of beholding the city, a third theme emerges in Procopius' description: the church's command of the sixth-century urban landscape. This theme forms the concluding image in the parallels and antitheseis, in the interplay of words and imagery of the opening paragraph of Saint Sophia's description.

This literary theme in the ekphrasis of the early Byzantine church appears in the sixth century. It is also fully documented in the archaeological evidence. The location of early Byzantine churches depended on the availability of land. Thus, some were built on vacant civic land, some on lots donated to the Church, and others occupied the sites of pagan temples. Most of them were very large and indeed dominated the surroundings. An early Christian basilica was built in the fifth century on the site of the temple of Aphrodite north of the agora of Aphrodisias in Asia Minor. The Christian church was much larger and more commanding than the pagan temple $e^{41}$. In contrast, other churches were small and un- pretentious next to large impressive pagan temples, as the "Temple Church" at Sardis ${ }^{42}$. Many churches were built on high grounds or raised platforms accessed with monumental staircases $^{43}$. But this was far from being the rule ${ }^{44}$. The preference for high grounds for many early Christian churches follows the Roman tradition of placing temples on podia or elevated $\operatorname{sites}^{45}$. Archaeological evidence indicates that early Byzantine churches were often built on a high podium so that they were raised above the surrounding buildings ${ }^{46}$. Other churches were built on hilltops offering spectacular views over a plain or the sea: the sixth-century Justinianic basilica on the summit of Mt Berenice of ancient Tiberias was constructed on a cliff from which a panoramic view over the Sea of Galilee could be enjoyed ${ }^{47}$; the emperors Zeno and Justinian built a church and a monastery on top of the mountain that dominated the city of Neapolis (mod. Nablus) ${ }^{48}$. In smaller settlements similar variety has been observed in the selection of sites for churches. In some small towns in the East, churches were architecturally totally integrated into the towns, with building materials and techniques similar to those of the towns' other buildings ${ }^{49}$. In numerous other sites, however, early Byzantine churches occupied the top of a hill on the slopes of which were built the settlements, or the summit of small forts ${ }^{50}$. Representative of the sixth-century urban planning is Justiniana Prima (Caričin Grad), where the bishop's church dominates the city on the hilltop surrounded by a strong wall ${ }^{51}$. In the new model of city emerging in the sixth century, the church was conveying a powerful statement of dominance over the ur-

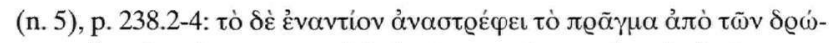

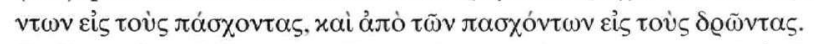
39. Procopius, Buildings I.1.27 (transl. H. B. Dewing, ed. Loeb): દ̇лñ̄-

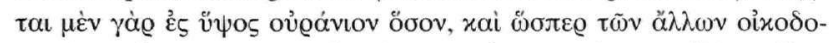

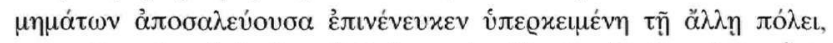

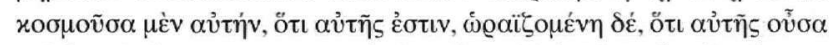

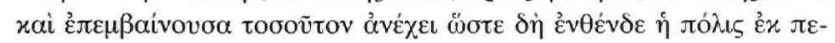

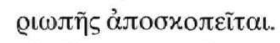

40. Cf. supra, n. 17.

41. Cf. R. Cormack, The Temple as the Cathedral, Aphrodisias Papers (eds Ch. Roueché and K. T. Erim), JRA, Suppl. 1, Ann Arbor 1990, p. 75-88.

42. G.M.A. Hanfmann, The Fourth Campaign at Sardis (1961), BASOR 166 (1962), p. 49-54.

43. Cf. R.H. Smith, A.W. McNicoll, The 1982 and 1983 Seasons at Pella of the Decapolis, BASOR 1986, Suppl. 24, p. 106, and the famous Cathedral Church at Gerasa.

44. J. Guyon and G. Cardi, L'église B, dite 'basilique cruciforme', in N. Duval, V. Popović (eds), Caričin Grad, I, Belgrade, Rome 1984, p. 12, $19 \mathrm{ff}$.

45. J. E. Packer, Report from Rome: The Imperial Fora, a Retrospec- tive, $A J A 101$ (1997), p. 327.

46. Cf., for example, Z. Weiss and E. Netzer, Zippori-1992/1993, Excavations and Surveys in Israel 14 (1994), p. 43.

47. Y. Hirschfeld, The Anchor Church at the Summit of Mt. Berenice, Tiberias, BiblArch 57 (1994), p. 122-133; id., Tiberias, Mt. Berenice 1992, Excavations and Surveys of Israel 14 (1994), p. 33-38.

48. Y. Magen, The Church of Mary Theotokos on Mount Gerizim, Christian Archaeology of the Holy Land, 1990.

49. B. de Vries, Jordan's Churches. Their Urban Context in Late Antiquity, BiblArch 51 (1988), p. 222-226.

50. For example, T. Gregory, Diporto: An Early Byzantine Maritime Settlement in the Gulf of Korinth, $\triangle X A E$ IB $^{\prime}$ (1984), p. 287-304, esp. 293, 295, 302, 304; S. Aydal et al., The Pisidian Survey 1995: Panemoteichos and Ören Tepe, AnatSt 47 (1997), p. 141-172; St. Mitchell, Pisidian Survey, AnatArch 1 (1995), p. 17.

51. N. Duval, L'architecture religieuse de Tsaritchin Grad dans le cadre de l'Illyricum oriental au VIe siècle, in Villes et peuplement dans l'Illyricum protobyzantin. Actes du colloque organisé par l'École française de Rome (Rome, 12-14 mai 1982), Rome 1984, p. 399-480, esp. 406-419. 
ban space. The theme of the visual interrelation of the church with the city is reflected in the mosaic representations of cities with churches of the sixth and seventh centuries ${ }^{52}$.

In conclusion, the rhetorical theme of beholding the praised city was developed in the early Byzantine period to create greater emphasis in the enkomiastikai ekphraseis. The Hellenistic city planning and the Roman way of depicting cities were the models for such descriptions. In the sixth century the ekphrasis of the church emerges in elaborate rhetorical compositions as a parallel to the city, but also as an opposition to it. Ultimately the church appears dominating the city. The development of this rhetorical theme is fully documented in the archaeological evidence. It corresponds to the historical reality of diminishing urban vitality in the sixth century. Thus through various rhetorical forms, the texts of the period depict the increasingly dominating role of the church in the urban architecture.

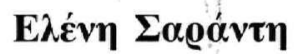

\section{ПАPATHPQNTA $\Sigma$ THN ПO $\Lambda$ H KA THN EKK $\Lambda H \Sigma I A:$

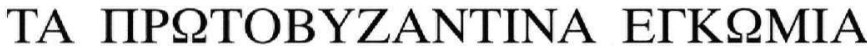 KAI ANTI $\Sigma$ TOIXE $\Sigma$ APXAIO $\Lambda$ OГIKE $\Sigma$ E $\Xi E \Lambda I \Xi E I \Sigma$}

K

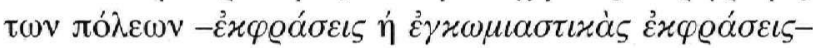

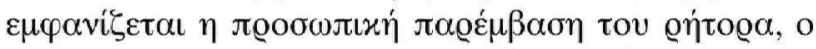

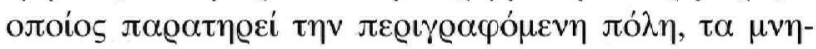

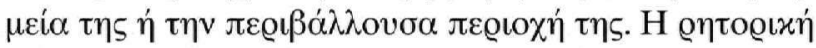
$\alpha v \tau \eta \dot{~ \tau \varepsilon \chi v ı x \eta ́ ~ \pi \varrho o \sigma \varepsilon ́ \delta ı \delta \varepsilon ~ \varepsilon ́ \mu \varphi \alpha \sigma \eta ~ \sigma \tau о ~ \varkappa \varepsilon ́ ́ \mu \varepsilon v o, ~ \pi \alpha \varrho \alpha \sigma \tau \alpha-~}$

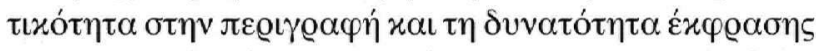

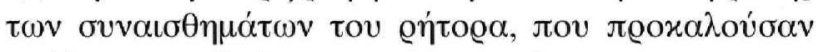

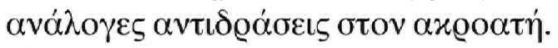

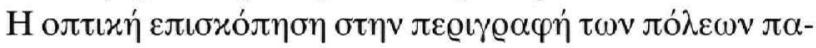

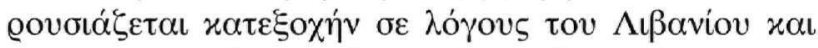
$\sigma \tau \alpha \Delta \iota v v \sigma \iota \alpha x \alpha$

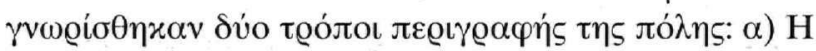

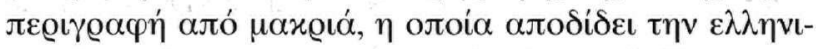

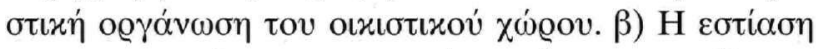

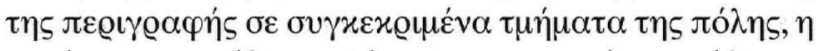

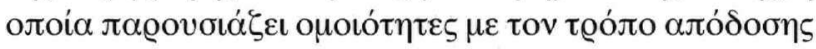

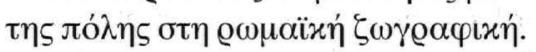

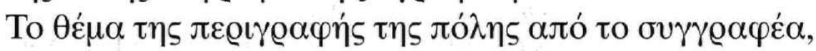

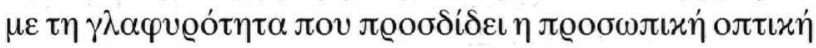

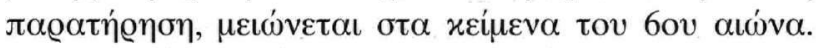

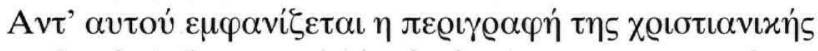

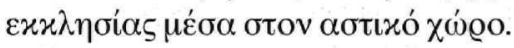

52. Cf. N. Duval, Représentations d'églises sur mosaïques, La Revue du Louvre et des Musées de France 22 (1972), p. 441-448; R. Farioli Campanati, Città, edifici e strutture architettoniche nei mosaici pavimentali

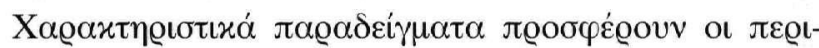

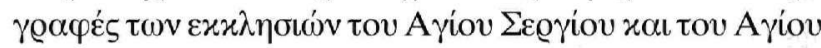

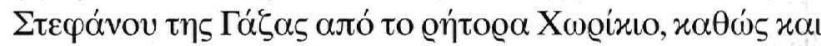

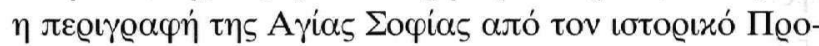

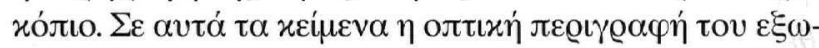

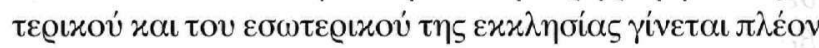

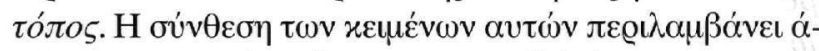

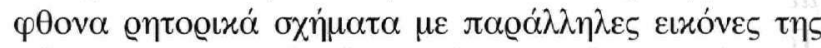

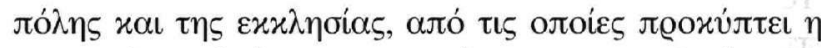

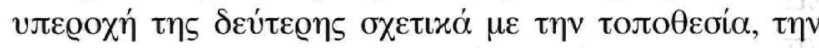

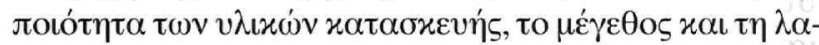

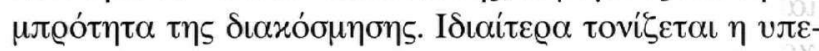

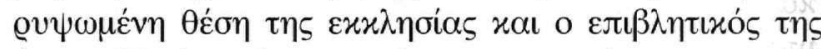

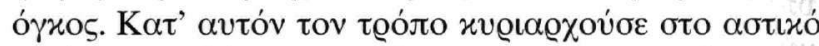

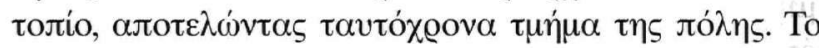

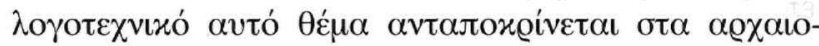

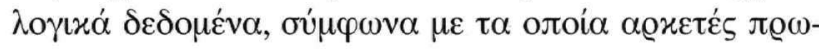

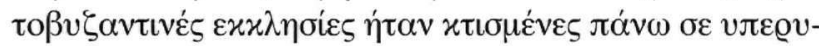

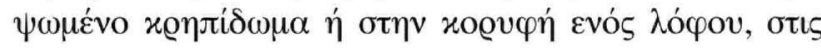

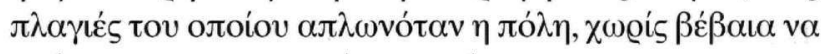

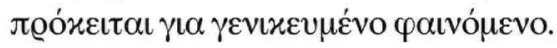

del vicino Oriente: Giordania e Siria, FelRav 1993-1994 (CXLV-CXLVIII), p. 259-291 with earlier bibliography. 